\title{
Preliminary Phytochemical and Pharmacological Investigations of Alpinia conchigera Griff. and Plumbago indica L.
}

\author{
Mohammed Ibrahim ${ }^{1}$, Joy Baura ${ }^{1}$, Qamrul Ahasan ${ }^{1}$, Torequl Islam ${ }^{1}$, Zilly Homa ${ }^{1}$, M. Mohi Uddin Chowdhury ${ }^{1}$, \\ Md. Aslam Hossain ${ }^{2}$ and Mohammad A. Rashid ${ }^{2}$ \\ ${ }^{1}$ Department of Pharmacy, Faculty of Science \& Engineering, Southern University Bangladesh, Chittagong, Bangladesh \\ ${ }^{2}$ Phytochemical Research Laboratory, Department of Pharmaceutical Chemistry, Faculty of Pharmacy, \\ University of Dhaka, Dhaka-1000, Bangladesh
}

\begin{abstract}
Preliminary phytochemical screenings with the crude extractives of Alpinia conchigera Griff. and Plumbago indica L. demonstrated the presence of alkaloids, steroids, saponins and reducing sugars. The antibacterial and antifungal activities of methanol extracts of $A$. conchigera and $P$. indica have been evaluated against 4 Gram positive and 7 Gram negative pathogenic bacteria and 7 fungi using ciprofloxacin and fluconazole as standards, respectively, where the extract showed varying degrees of antimicrobial activity with zone of inhibition ranging from 15.0 to $27.0 \mathrm{~mm}$. A. conchigera demonstrated significant zone of inhibition against Aspergillus niger, Blastomyces dermatitidis, Staphylococcus aureus, Salmonella typhi, Shigella dysenteriae, Bacillus cereus Pseudomonas aeruginosa, Shigella sonnei, Vibrio cholerae while P. indica revealed strong inhibitory activity against Candida albicans, Blastomyces dermatitidis, Bacillus cereus, Staphylococcus aureus, Escherichia coli and Salmonella paratyphi. The MICs of the both plant extractives were found to be $31.25 \mu \mathrm{g} / \mathrm{ml}$ against B. cereus, S. paratyphi, $V$. cholerae, A. niger and B. dermatitidis. In the brine shrimp lethality bioassay, the $\mathrm{LC}_{50}$ and $\mathrm{LC}_{90}$ of $A$. conchigera and $P$. indica were found to be $6.1 \& 12.2 \mu \mathrm{g} / \mathrm{ml}$ and $5.0 \& 12.0 \mu \mathrm{g} / \mathrm{ml}$, respectively. A significant dose dependent antidiarrhoeal, antimotility and analgesic activities were observed during screening in mice.
\end{abstract}

Key words: Alpinia conchigera, Plumbago indica, analgesic, antidiarrhoeal, antimicrobial, antimotility, cytotoxicity, MIC.

\section{Introduction}

Many of the plant materials used in traditional medicines are readily available in rural areas and this has made traditional medicine relatively cheaper than modern medicine (Apulu et al., 1994). Bangladesh is a developing country and it covers a large number of poor people having no access to modern medical support. Most of them are usually dependent upon the traditional practitioners for their health troubles.

Alpinia conchigera Griff. (Family: Zingiberaceae; Bengali: Burkill), a slender herb, about 0.6 to $1.5 \mathrm{~m}$ tall, is native to Bangladesh, Cambodia, India and Indonesia and naturalized to Laos, Malaysia, Myanmar, Thailand and Vietnam. Traditionally it is used in gastric pain, diarrhoea and dysentery in the southeast region of Bangladesh (Yusuf et al., 2007).

Plumbago indica L. (Family: Plumbaginaceae; Bengali: Agnichita), a perennial evergreen shrub with about 2 to 4 feet in height is traditionally used in skin disease, anaemia, irregular menstruation and leucorrhoea in the southeast area of Bangladesh (Yusuf et al., 2007).

A comprehensive literature search revealed that $A$. conchigera have been studied for chemical constituents (Wong et al., 2005), antimicrobial (Wannissorn et al., 2009), gastroprotective (Pongpiriyadacha et al, 2008) and anticancer activities. On the other hand, $P$. indica have been subjected for preliminary phytochemical screening as well as antioxidant and antibacterial activities against few microorganisms. The antifungal activity of Plumbago species against $C$. gloeosporidodes has also been documented.

As a part of our continuing effect to study the medicinal plants of Bangladesh (Kaisar et al., 2011; Kabir et al., 2010), we evaluated the phytoconstituents, antimicrobial, antidiarrhoeal, antimotility and analgesic activities of crude methanol extract of A. conchigera and $P$. indica and we in here report the results of our preliminary investigation. 


\section{Materials and Methods}

Collection and identification: The plants selected for the present work, A. conchigera Griff. (Family: Zingiberaceae) and $P$. indica L. (Family: Plumbaginaceae), were collected from Naramuk, Rajasthali of Rangamati district, Bangladesh in October, 2010 and were identified at the Forest Research Institute; Chittagong, Bangladesh where voucher specimens have been maintained.

Extraction: The plant materials were subjected to drying in an oven below $40^{\circ} \mathrm{c}$. Then the crude dried plant was ground into coarse powder and subjected to hot extraction with $97 \%$ methanol by using a Soxhlet apparatus. The extraction was carried out about $18 \mathrm{hrs}$ and filtered through a cotton plug followed by Whatman filter paper number \# 1 . The extract was then concentrated by using rotary evaporator.

Preliminary phytochemical screenings: The crude extracts were subjected to various tests (Table 1) for determination of chemical nature of the phytoconstituents.(Ali, 2009; Evans, 1934; Finer, 1983).

Antimicrobial screening: The antibacterial and antifungal activities of the crude extracts were evaluated by the disc diffusion method (Aboaba et al., 2001) against 4 Gram positive and 7 Gram negative pathogenic bacteria and 7 fungi (Table-2) using ciprofloxacin and fluconazole as standards. The organisms were obtained as pure culture from the Faculty of Biology, University of Chittagong, Bangladesh. The antimicrobial activity of the test agents was expressed by measuring the diameter of zone of inhibition expressed in $\mathrm{mm}$. The experiments were carried out in triplicate.

Minimum inhibitory concentration (MIC): The minimum inhibitory concentration (MIC) of all the extract was determined by the serial dilution technique (Andrews et al., 2001) in nutrient broth medium, containing graded concentration of the plant extracts and inoculated test organisms.

Brine shrimp lethality bioassay: Brine shrimp lethality bioassay (Laughlin, 1988; Lughilin, 1992; Maghrani et al., 2005; Persoone, 1980) technique was applied for determination of general toxic property of the plant extractives.

Antidiarrhoeal Activity: This test was carried out by castor oil-induced diarrhoea in mice (Thomas, 2001).
Young Swiss albino mice, average weight 18-25gm of either sex were employed in the experiment. The animals were divided into control, positive control and two test groups containing five mice in each. Control group received 1\% Tween-80 (10 ml/kg p.o). The positive control group received loperamide ( $3 \mathrm{mg} / \mathrm{kg}$ p.o) while the test groups received the methanol extract (250 and 500 $\mathrm{mg} / \mathrm{kg}$ ) orally. Acute diarrhoea was produced by oral administration of $0.4 \mathrm{ml}$ of castor oil to each mouse. Then the latency period and total diarrheic secretion were counted for 4 hrs.

Antimotility activity: In the charcoal-meal defecation method (Hérida and Maria, 2004) the experimental animals (Swiss albino mice) were divided into six groups each containing five mice. After fasting for $180 \mathrm{~min}$ the mice were administered with loperamide (IMOTIL, 2 mg/cap. Square Pharmaceuticals Ltd., Bangladesh) (5 $\mathrm{mg} / \mathrm{kg}$ b.w. orally) as positive control, $1 \%$ Tween-80 as negative control group and $250 \mathrm{mg} / \mathrm{kg}$ b.w. and $500 \mathrm{mg} / \mathrm{kg}$ b.w. extracts as the test drugs. After $90 \mathrm{~min}, 0.3 \mathrm{ml}$ of an aqueous suspension of $5 \%$ charcoal was orally administered to each animal. After 60 min the mice had free access to food and the animals were observed at $5 \mathrm{~min}$ intervals until faeces with charcoal were eliminated. The maximum time of observation was $450 \mathrm{~min}$. Charcoal was observed on the faeces using normal light when it was easily visible, or using a microscope to help the detection of black spots. The results were based on the time for the charcoal to be eliminated.

Analgesic activity: For acetic acid induced (Whittle, 1964. ) analgesic test, the samples, control and diclofenacNa were given orally by means of a feeding needle to the test, control and positive control groups, respectively. After 30 minutes acute pain was induced by acetic acid solution $(0.7 \%, 15 \mathrm{ml} / \mathrm{kg}$; i.p. to each mouse) and the number of squirms (writhing) due to pain in the abdominal cavity was calculated for 20 minutes after administration of acetic acid.

Statistical analysis: The primary data obtained from the experiments were manipulated as the source of responses. For each of the extracts, three samples were prepared for each of the bioassays. Data were expressed as mean \pm SEM (standard error of mean). Statistical differences between extract activities were determined using ANOVA followed by Least Significant Difference 
(LSD) testing. Differences were considered statistically significant when $\mathrm{p}<0.5$.

\section{Results and Discussion}

Preliminary phytochemical screenings: The crude extractives when tested with various chemical reagents demonstrated the presence of alkaloids, glycosides, saponins, tannins, steroids and reducing sugars as shown in Table 1.
Antimicrobial screening: The extracts of both plants showed varying degrees of antimicrobial activity (Table 2) with zone of inhibition ranging from 15.0 to $27.0 \mathrm{~mm}$. A. conchigera demonstrated significant zone of inhibition against A. niger, B. dermatitidis, S. aureus, S. typhi, Sh. dysenteriae, B. cereus $P$. aeruginosa, Sh. sonnei, V. cholerae while $P$. indica revealed strong inhibitory activity towards C. albicans, B. dermatitidis, B. cereus, $S$. aureus, E. coli and S. paratyphi. Ciprofloxacin and fluconazole were taken as standards for antibacterial and antifungal test.

Table 1. Chemical groups present in methanol extracts of $A$. conchigera and $P$. indica

\begin{tabular}{|c|c|c|c|}
\hline Test for & Name of the test/ Reagent & A. conchigera & P. indica \\
\hline \multirow{2}{*}{ Reducing sugar } & Fehling's solution test & + & + \\
\hline & Benedict's test & + & + \\
\hline Steroids & Salkowski test & + & + \\
\hline \multirow{2}{*}{ Glycosides } & Salkowski test & - & + \\
\hline & Libermann-burchared test & - & - \\
\hline \multirow{4}{*}{ Tannins } & Ferric chloride & - & - \\
\hline & Potassium dichromate & - & - \\
\hline & Mayer's test & + & - \\
\hline & Dragendorff's reagent & + & + \\
\hline \multirow{3}{*}{ Alkaloids } & Wagner's reagent & + & + \\
\hline & Hager’s reagent & + & + \\
\hline & Tannic acid & + & + \\
\hline Saponins & Shaking test for foaming & + & + \\
\hline
\end{tabular}

+ = presence, - = absence

Table 2. Antimicrobial activity of methanol extracts of $A$. conchigera and $P$. indica (500 $\mathrm{\mu g} / \mathrm{disc})$ and standard (50 $\mathrm{\mu g} / \mathrm{disc})$

\begin{tabular}{lccc}
\hline \multirow{2}{*}{ Test microorganisms } & \multicolumn{2}{c}{ Zone of inhibition (mm) } \\
\cline { 2 - 3 } & \multicolumn{2}{c}{ MeOH extract of } & Standard \\
\cline { 2 - 3 } & & A. conchigera & Ciprofloxacin \\
\hline Gram positive bacteria & $25.0 \pm 0.58^{\mathrm{b}}$ & $23.0 \pm 0.34^{\mathrm{b}}$ & $28.0 \pm 0.34^{\mathrm{b}}$ \\
\hline Bacillus cereus & $17.0 \pm 0.34^{\mathrm{e}}$ & $21.0 \pm 1.17$ & $25.0 \pm 0.67^{\mathrm{e}}$ \\
B. megaterium & $18.0 \pm 0.34^{\mathrm{a}}$ & $20.0 \pm 0.34^{\mathrm{b}}$ & $24.0 \pm 0.34^{\mathrm{b}}$ \\
B. subtilis & $24.0 \pm 0.58^{\mathrm{b}}$ & $24.0 \pm 1.17$ & $27.5 \pm 0.34^{\mathrm{d}}$ \\
Staphylococcus aureus & & & $28.0 \pm 0.34^{\mathrm{c}}$ \\
\hline Gram negative bacteria & $23.0 \pm 0.34^{\mathrm{b}}$ & $22.0 \pm 0.58^{\mathrm{e}}$ & $31.0 \pm 0.34^{\mathrm{e}}$ \\
\hline Escherichia coli & $21.0 \pm 0.67^{\mathrm{c}}$ & $23.0 \pm 1.21$ & $23.5 \pm 0.34^{\mathrm{b}}$ \\
Pseudomonas aeruginosa & $22.0 \pm 0.34^{\mathrm{d}}$ & $20.0 \pm 0.34^{\mathrm{b}}$ & $23.67 \pm 0.89$ \\
Salmonella paratyphi & $20.0 \pm 0.34^{\mathrm{d}}$ & $23.67 \pm 0.89$ & $32.0 \pm 0.34^{\mathrm{b}}$ \\
S. typhi & $21.0 \pm 0.34^{\mathrm{a}}$ & $23.5 \pm 0.58^{\mathrm{e}}$ & $27.0 \pm 0.58^{\mathrm{e}}$ \\
Shigella dysenteriae & $18.0 \pm 0.34^{\mathrm{a}}$ & $23.0 \pm 0.34^{\mathrm{b}}$ & $24.5 \pm 0.34^{\mathrm{b}}$ \\
Sh. sonnei & $19.0 \pm 0.34^{\mathrm{d}}$ & $19.33 \pm 0.34^{\mathrm{b}}$ & Fluconazole $^{\mathrm{b}}$ \\
Vibrio cholerae & & & $27.0 \pm 0.34^{\mathrm{b}}$ \\
\hline Fungi & $21.0 \pm 0.34^{\mathrm{a}}$ & $26.0 \pm 0.58$ & $22.0 \pm 0.34^{\mathrm{a}}$ \\
\hline Aspergillus niger & $25.0 \pm 0.34^{\mathrm{a}}$ & $25.0 \pm 0.34^{\mathrm{a}}$ & $26.0 \pm 0.58$ \\
Blastomyces dermatitidis & $27.0 \pm 0.34^{\mathrm{b}}$ & $15.0 \pm 0.58$ & $21.0 \pm 0.34^{\mathrm{a}}$ \\
Candida albicans & $20.0 \pm 0.34^{\mathrm{e}}$ & $15.0 \pm 0.89$ & $23.0 \pm 0.34^{\mathrm{a}}$ \\
Cryptococcus neoformans & $25.0 \pm 0.34^{\mathrm{e}}$ & $20.0 \pm 0.34^{\mathrm{a}}$ & $22.0 \pm 0.34^{\mathrm{a}}$ \\
Microsporum spp. & $20.0 \pm 0.34^{\mathrm{a}}$ & $19.0 \pm 0.34^{\mathrm{a}}$ & $29.0 \pm 0.34^{\mathrm{a}}$ \\
Pityrosporum ovale & $20.0 \pm 0.58^{\mathrm{d}}$ & $24.0 \pm 0.58$ & \\
Trichophyton spp. & & & \\
\hline
\end{tabular}


Minimum inhibitory concentration (MIC): During the MIC determination, the methanol extract of both of $A$. conchigera and $P$. indica inhibited the growth of test organisms between 31.25-62.50 $\mu \mathrm{g} / \mathrm{ml}$ (Table 3). The low MIC values of the extract of $A$. conchigera, against $A$. niger, B. cereus, B. dermatitidis, S. typhi, S. sonnei, and $V$. cholerae that of $P$. indica against $B$. cereus, $B$. dermatitidis, C. albicans, E. coli, S. aureus and $S$. paratyphi suggest the presence of strong antimicrobial compounds in the extractives. Here, ciprofloxacin and fluconazole were taken as standard antibacterial and antifungal agent, respectively.

Table 3. Minimum inhibitory concentration (MIC) of methanol extract of $A$. conchigera and $P$. indica

\begin{tabular}{lcc}
\hline \multirow{2}{*}{ Test organisms } & \multicolumn{2}{c}{$\begin{array}{c}\text { Minimum inhibitory concentration } \\
(\mu \mathrm{ml})\end{array}$} \\
\cline { 2 - 3 } Bacteria & A. conchigera & P. indica \\
\hline Bacillus cereus & 31.25 & 31.25 \\
Escherichia coli & 62.50 & 31.25 \\
Staphylococcus aureus & 62.50 & 62.50 \\
Salmonella paratyphi & - & 31.25 \\
S. typhi & 31.25 & 62.50 \\
Shigella dysenteriae & - & 62.50 \\
Sh. sonnei & 31.25 & - \\
Vibrio cholerae & 31.25 & - \\
\hline Fungi & & 31.25 \\
\hline Aspergillus niger & 31.25 & 31.25 \\
Blastomyces & 31.25 & 31.25 \\
dermatitidis & & \\
Candida albicans & 62.50 & \\
\hline
\end{tabular}

(-): MIC $>100 \mu \mathrm{g} / \mathrm{ml}$

Brine shrimp lethality bioassay: During brine shrimp lethality bioassay, the $\mathrm{LC}_{50}$ and $\mathrm{LC}_{90}$ of methanol extracts of $A$. conchigera and $P$. indica (Table 4) were found to 6.1- \& 12.2 - and 5.0- \& $12.0 \mu \mathrm{g} / \mathrm{ml}$, respectively; as compared to 0.44 - and $0.82 \mu \mathrm{g} / \mathrm{ml}$ for standard Vincristine sulphate.

Antidiarrhoeal activity: During antidiarrhoeal activity by castor oil induced test in mice, the methanol extract of $A$. conchigera and $P$. indica produced a dose dependent and significant antidiarrhoeal episode (Table 5). The onset of action and the total diarrheic faces were found to be
$1.32 \mathrm{hr} \& 9.0$ and $1.24 \mathrm{hr} \& 8.6$ at $500 \mathrm{mg} / \mathrm{kg}$ for $A$. conchigera and $P$. indica, respectively. The half dose of the crude extract also prolonged the latency period and reduced the defecation in comparison to the standard loperamide.

Table 4. Brine shrimp lethality bioassay of methanol extract of $A$. conchigera and $P$. indica

\begin{tabular}{lcc}
\hline Sample & $\mathrm{LC}_{50}(\mu \mathrm{g} / \mathrm{ml})$ & $\mathrm{LC}_{90}(\mu \mathrm{g} / \mathrm{ml})$ \\
\hline Vincristine sulphate & 0.44 & 0.82 \\
A. conchigera & 6.1 & 12.2 \\
P. indica & 5.0 & 12.0 \\
\hline
\end{tabular}

Table 5. Antidiarrhoeal episode of methanol extract of $A$. conchigera and $P$. indica

\begin{tabular}{lll}
\hline Sample & TLP $(\mathrm{hr})$ & TNF \\
\hline Loperamide $(3 \mathrm{mg} / \mathrm{kg})$ & $1.35 \pm 6.02^{\mathrm{a}}$ & $6.4 \pm 1.151^{\mathrm{a}}$ \\
A. conchigera $(250 \mathrm{mg} / \mathrm{kg})$ & $1.16 \pm 3.88^{\mathrm{b}}$ & $13.0 \pm 0.79^{\mathrm{b}}$ \\
A. conchigera $(500 \mathrm{mg} / \mathrm{kg})$ & $1.32 \pm 2.86^{\mathrm{b}}$ & $9.0 \pm 1.369^{\mathrm{b}}$ \\
$P$. indica $(250 \mathrm{mg} / \mathrm{kg})$ & $0.94 \pm 4.64^{\mathrm{b}}$ & $12.6 \pm 2.10^{\mathrm{b}}$ \\
$P$. indica $(500 \mathrm{mg} / \mathrm{kg})$ & $1.24 \pm 5.25^{\mathrm{b}}$ & $8.6 \pm 1.20^{\mathrm{b}}$ \\
\hline${ }^{\mathrm{a}}<0.02,{ }^{\mathrm{b}}<0.05$ & \\
TLP: Total latent period (Mean latent period \pm SEM); TNF: Total \\
number of faeces (Mean defecation \pm SEM);
\end{tabular}

Antimotility activity: In antimotility activity by charcoal meal defecation, the extract produced significant delay for total excretion of charcoal from the intestinal cavity of the mice (Table 6). The time taken for charcoal meal defecation of $A$. conchigera and $P$. indica at 500 $\mathrm{mg} / \mathrm{kg}$ b.w. were $370.8 \mathrm{~min}$ and $376.2 \mathrm{~min}$, respectively. The half dose of the crude extract also delayed the defecation period in comparison to the standard loperamide.

Table 6. Antimotility activity of methanol extract of $A$. conchigera and $P$. indica

\begin{tabular}{lc}
\hline \multicolumn{1}{c}{ Treatment groups } & $\begin{array}{c}\text { Time until charcoal } \\
\text { defecation (Min) }\end{array}$ \\
\hline Loperamide $(5 \mathrm{mg} / \mathrm{kg})$ & $379.8 \pm 9.59$ \\
A. conchigera $(250 \mathrm{mg} / \mathrm{kg})$ & $297.0 \pm 15.06$ \\
A. conchigera $(500 \mathrm{mg} / \mathrm{kg})$ & $370.8 \pm 6.024$ \\
P. indica $(250 \mathrm{mg} / \mathrm{kg})$ & $302.4 \pm 15.11^{\mathrm{b}}$ \\
$P$. indica $(500 \mathrm{mg} / \mathrm{kg})$ & $376.2 \pm 5.57^{\mathrm{b}}$ \\
\hline${ }^{\mathrm{a}}<0.001,{ }^{\mathrm{b}} \mathrm{p}<0.05$. Total charcoal defecation: (Mean defecation period \pm \\
SEM)
\end{tabular}


Analgesic activity: During acetic acid induced writhing test for the analgesic activity in mice, the pain killer dose $500 \mathrm{mg} / \mathrm{kg}$ was found to be significant active in comparison to the standard, diclofenac-Na (Table 7). Total writhing by this dose were 32.6 and 31.4 for A. conchigera and $P$. indica, respectively; while the standard drug was 29.2. Both the selected dose for the extract also produced a dose dependent activity.

Table 7. Analgesic activity of methanol extract of $A$. conchigera and $P$. indica

\begin{tabular}{ll}
\hline Sample & No. of Writhing \\
\hline Diclofenac-Na $(25 \mathrm{mg} / \mathrm{kg})$ & $29.2 \pm 4.307^{\mathrm{b}}$ \\
A. conchigera. $(250 \mathrm{mg} / \mathrm{kg})$ & $38.6 \pm 5.392^{\mathrm{b}}$ \\
A. conchigera $500 \mathrm{mg} / \mathrm{kg})$ & $32.6 \pm 5.76^{\mathrm{b}}$ \\
P. indica. $(250 \mathrm{mg} / \mathrm{kg})$ & $37.8 \pm 4.82^{\mathrm{b}}$ \\
P. indica $(500 \mathrm{mg} / \mathrm{kg})$ & $31.4 \pm 5.03^{\mathrm{b}}$ \\
\hline${ }^{\mathrm{a}}<0.001,{ }^{\mathrm{b}} \mathrm{p}<0.05 ;$ No. of writhing: (Mean writhing \pm SEM);
\end{tabular}

\section{Conclusion}

From the study, it is evident that, the methanol extract of $A$. conchigera and $P$. indica showed moderate to strong antimicrobial activity, mild cytotoxicity against brine shrimp nauplii, significant dose dependent antidiarrhoeal, antimotility and analgesic activities. Further investigation is required to isolate the bioactive moieties. Bioactivities demonstrated by the extracts support the traditional uses of the plant in various diseases.

\section{References}

Aboaba, O.O., Smith, S.I. and Olude, F.O. 2006. Antibacterial effect of edible plant extracts on Escherichia coli 0157:H7. Pak. J. Nutr., 5, 325-327.

Aboaba, O.O. and Efuwape, B.M. 2001. Antibacterial properties of some Nigerian spices. Bio. Res. Comm., 13, 183-188.

Andrews, J.M. 2001. Determination of minimum inhibitory concentrations. J. Antimicrobial Chemothe., 48, 5-16.

Apollo, N., Dada, J.O., Odama, L.E. and Galadima, M. 1994. Antibacterial activities of aqueous extracts of some Nigerian medicinal plants. Nigerian J. Bot., 7, 45-48.

Ali, M. 2009. Text Book of Pharmacognosy, New edn. CBS Publishers and Distributors, New Delhi, India, pp. 96-97, 140 \& 283.
Bhal, B.S. and Bhal, A. 1992. A Text Book of Organic Chemistry, $13^{\text {th }}$ edn. S. Chand \& Company Ltd. pp. 5-6, $111-12$ \& 114.

Brunton, L.L. 1996. Agents affecting gastrointestinal water efflux and motility; emesis and anti-emetics; bile acids and pancreatic enzymes, $9^{\text {th }}$ edn. pp. 917-36.

Evans, W.C. 1934. Trease and Evans Pharmacognosy, $15^{\text {th }}$ edn. p. 64.

Finer, I.L.1983. Organic Chemistry, Vol. 2, $5^{\text {th }}$ edn. Longman, Singapore Publisher Ltd. pp. 518, 767.

Ghani, A. 2003. Medicinal Plants of Bangladesh, $2^{\text {nd }}$ edn. Asiatic society of Bangladesh, Dhaka, p. 418.

Hérida, R., Nunes, M., Maria, B. and Bastos, L. 2004. Protocol to refine intestinal motility test in mice, 38, 257-260.

Kaisar, M.A. Rahman, M.S. Rahman, M.Z. Hasan, C.M. and Rashid, M.A. 2011. A review on phytochemicals from some medicinal plants of Bangladesh. J. Pharm. Nutri. Sci., 1, 8795.

Kabir, S., Rahman, M.S., Chowdhury, A.M., Hasan C.M. and Rashid, M.A. 2010. An unusual bisnor clerodane diterpenoid from polygonum simiarum. Nat. Prod. Commun., 5, 1543-1546.

Laughlin, M.J.L. 1988. Brine Shrimp and Crown Gall Tumors: simple Bioassay for the Discovery of Plant Antitumor Agents. Proceedings, NIH Workshop, Bioassays for Discovery of Antitumor and antiviral Agent from Natural Sources. Bethesda, 18-19, 220.

Laties, V. 1987. Control of animal pain and distress in behavioral studies that use food deprivation or aversive stimuli. 191, 1290-1.

Lughilin, M.J.L. 1992. Bench-top Bioassay for the Discovery of Bioactive Compound in Higher Plants. Brenesic, 29.

Maghrani, M., Michel, J.B., Eddouks, M. and UFR PNPE, P.B. 2005. 21 Errachidia, Morocco, Hypoglycaemic activity of Retama raetam in rats, $\mathbf{1 9}, 125-8$.

Yusuf, M.A. Wahab, M.Y., Chowdhury, J.U. and Begum, J. 2007. Some tribal medicinal plants of Chittagong Hill Tracts, Bangladesh. Bangladesh J. Plant Taxon., 14, 117128.

Paech, K. and Tracey, M.V. Modern Method of Plant Analysis, 4, 373.

Persoone, G. 1980. Proceeding of the International Symposium on Brine Shrimp, Artemia Salina, Belgium, Vol. 1-3.

Srivastava, O.P. 1984. Technology for Evaluation of Antimicrobial Properties of Natural Product. In: The use of Pharmacological Tech. for evaluation of natural products, Edited by Dewn, b. N., Srinal, R. C. 75.

Shoba, F.G., Thomas, M. 2001. Study of antidiarrhoeal activity of four medicinal plants in castor oil induced diarrhea. $J$. Ethnopharmacol., 76, 73-76.

Whittle, B.A. 1964. The use of changes in capillary permeability in mice to distinguish between narcotic and non-narcotic analgesic. Br. J. Pharmacol. Chemo., 22, 246. 